\title{
Two New Ornithogalum Species from South West Africa
}

\author{
by \\ A. A. Obermeyer
}

Ornithogalum candidum Oberm., sp. nov., $O$. rautanenii Schinz affinis, sed plantae robustiores, foliis latioribus, perianthio majore staminum filamentis ex appendiculatis differt.

Bulbus angustus in collo longo productus. Folia 2 (raro 3) linearia ad late linearia ad basin vaginata. apice acuminata. $6-15 \mathrm{~cm}$ longa. $6-12 \mathrm{~mm}$ lata patentia glauca glabra striata margine saepe undulata. Racemus simplex ad 20-florus; scapus validus teres; bracteae minorae membranaceae; pedicelli filiformes patentes. Perianthium candidum circa $2 \mathrm{~cm}$ diam., segmentis anguste oblongis. Staminum filamenta anguste lanceolato-subulata. Ovarium ovoideum sessile, ovulus in quoque locula 8. Capsula late obovoidea chartacea; semina applanata oblanceolata nigra.

South West Africa. - 2317 Rehoboth: Büllsponter Fläche. Giess 388 (PRE, holo.; M; WIND); Form Vrede, REH 433, Giess 9/10. 2417 Mariental: between Mariental and Aris, Werdermann \& Oberdieck 2268; farm Witvley near Mariental, Giess 3878; Swartrand. \pm 30 miles W. of Mariental, Basson 146. 2115 Karibib: farm Nudis (Altenbrunn). Sevdel 245.

Bulb narrowly ovoid, $2-4 \mathrm{~cm}$ in diam., produced into a neck $8-10 \mathrm{~cm}$ long, outer covering papery, rough, greyish- or light brown. Leaves 2, rarely 3. linear to broadly linear, up to $15 \mathrm{~cm}$ long and $1.2(-2) \mathrm{cm}$ broad, clasping below, spreading. apex acuminate often laxly curled upwards, the margins usually wavy and involute, glaucous, glabrous, striate. Raceme simple. up to $15 \mathrm{~cm}$ high and up to 20-flowered; scape terete. firm, bracts small, ovate-acuminate. clasping. membranous; pedicels filiform, $1-3 \mathrm{~cm}$ long. patent. becoming firm in fruit. Flowers with a white shiny star-shaped perianth about $2 \mathrm{~cm}$ in diam.. segments broadly linear. $1 \mathrm{~cm}$ long and $4 \mathrm{~mm}$ broad. apex obtuse, with a broad 5-nerved midrib. Stamens somewhat shorter than the perianth-segments; filaments linear, anthers versatile. introrse. Ovary narrowly ovoid. sessile, with about 8 ovules per locule. style terete, stigma apical, papillate. Capsule broadly obovoid, 3-angled, about $1 \mathrm{~cm}$ long. chartaceous; seeds flattened, oblanceolate in outline, about $6 \mathrm{~mm}$ long. tapering to the funiculus, with a blackish-brown shiny loose skin (uncertain if seeds were mature).

Apparently confined to the Rehoboth-Mariental region although there is one record from Karibib. Found in open stands and covering extensive areas. According to collectors the flowers appear in their thousands after the first rains and cover the ground with a white. shiny carpet and on the ridges the flower masses resemble snowdrifts. Mr. W. Giess, who collected the species in 

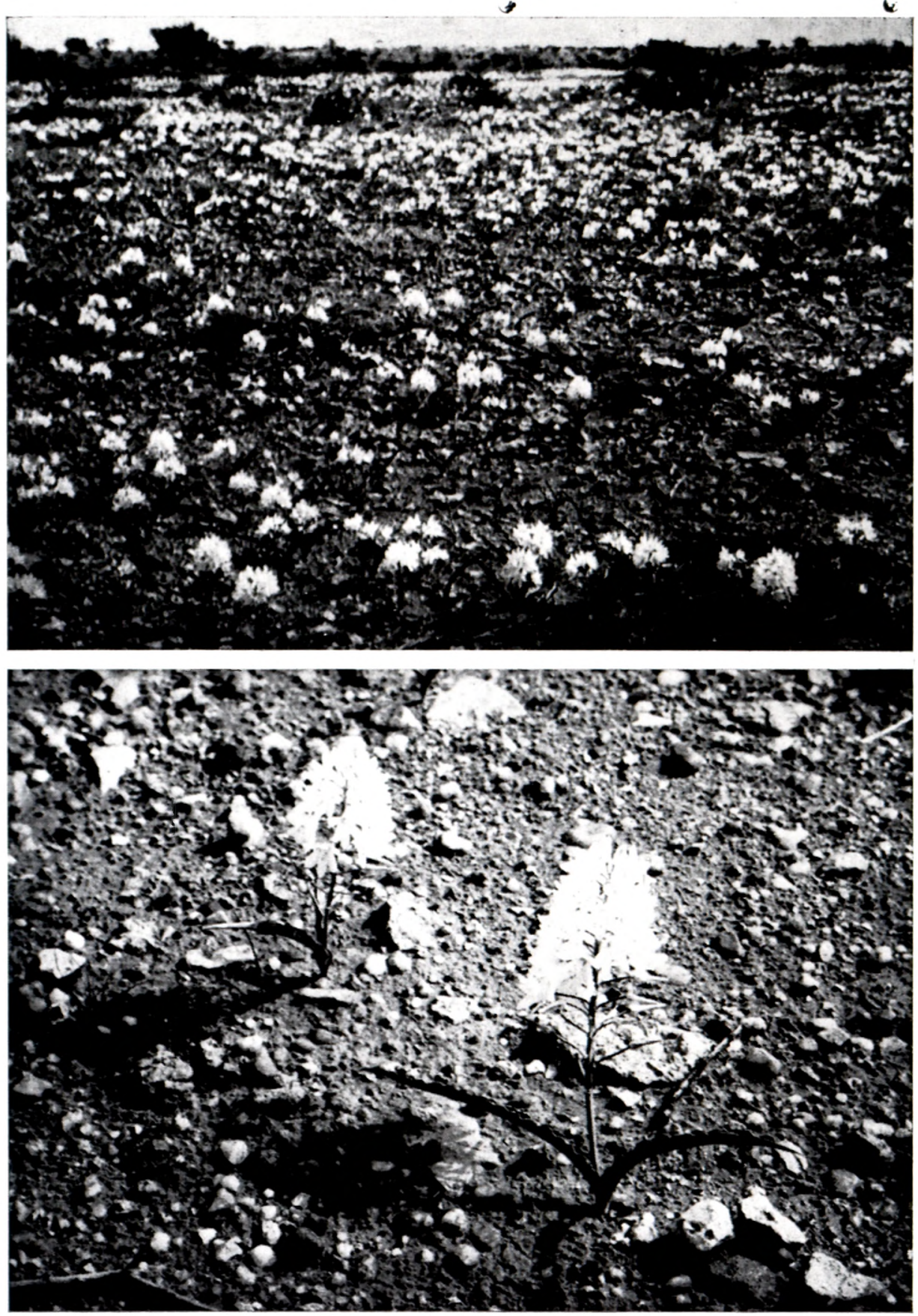

Plate 1. - Ornithogalum candidum, Farm Vrede, Rehoboth, South West Africa (Giess 9110). (Photos by W. Giess). 
several localities, noted that they preferred coarse quartzite gravel with underlying limestone but were absent from pure limestone or in red sand. They were eaten by animals which is surprising since species of Ornithogalum are known to be very poisonous.

var. tubiforme Oberm., var. nov. Perianthii segmentis ad basin connati. holo.).

South West Arrica. - 2317 (Rehoboth): farm Buellsport, Strey 2624 (PRE.

The fusion of the bases of the perianth-segments to form a short tube about $3 \mathrm{~mm}$ long is very unusual for this genus. The stamens are fused to the tube at the base but exserted above it. The leaves are narrow and folded, c. $2 \mathrm{~mm}$ wide.

Ornithogalum recurvum Oberm., sp. nov., O. rautanenii Schinz affinis, sed plantis majoribus, foliis latioribus, racemis elongatis, perianthii segmentis recurvis differt.

Planta ad $55 \mathrm{~cm}$ alta. Bulbus oblongo-globosus $10 \mathrm{~cm}$ longus, $5 \mathrm{~cm}$ diam., tunicis tenuibus brunneis transverse striatis. Folia c. 7 lineari-lanceolata ad $27 \mathrm{~cm}$ longa, $3 \mathrm{~cm}$ lata, ad basin vaginata apice attenuata, glabra glauca nitida. Racemus elongatus c. $35 \mathrm{~cm}$ longus; scapus teretus, bracteis minutis subulatis; pedicelli filiformes patentes ad $18 \mathrm{~mm}$ longi. Perianthii segmenta recurvata late linearia alba. Staminum filamenta in dimidio inferiore abrupte expansa in squamam latam, parte superiore erecta stylos cingentia. Ovarium disco basali leviter 6lobato, infra in stipite brevi contractum. Capsula late triangularis; semina discoidea nigra.

South West Arrica. - 1712 (Posto Velo): Kaokoveld. banks of the Kunene River at long. 1226, lat. 1715, among rocks in mountains, Story 5848 (PRE, holo., bulb cultivated at PRE). 1812 (Sanitatas): flats near waterhole at Orupembe, gravelly calcareous soil, De Winter \& Leistner 5732 (fruiting).

Bulb oblong, $10 \mathrm{~cm}$ long and $5 \mathrm{~cm}$ in diam. covered by thin shiny brown transversely striate scales; neck absent. Leaves rosulate, erect. about 7 . linearlanceolate, up to $27 \mathrm{~cm}$ long and $3.5 \mathrm{~cm}$ broad, clasping at the base, apex attenuate, glabrous, dark glaucous green, shiny. Raceme overtopping leaf-rosette (in the cultivated type-specimen the scape is up to $30 \mathrm{~cm}$ long and straight) or about equal to the scape, which is bent outwards near the middle; with a few minute sterile subulate bracts above; fertile bracts similar. Flowers up to 40 . on patent filiform pedicels up to $2 \mathrm{~cm}$ long. which become wiry in fruit. Perianth with the segments recurved, their tips touching the apex of the pedicel, broadly linear, $8 \mathrm{~mm}$ long and $1.5 \mathrm{~mm}$ broad, white with a broad green 3-5 nerved central band, apex obtuse cucullate, barbate. Stamens erect, filaments expanded in lower half to form a square base which folds inwards above around the ovary from where the filiform upper part then forms a connivent tube around the style; anthers versatile, introrse. Ovary expanded below in a shallowly 6lobed disc from a shortly stipitate base, turbinate above, with about 18 biseriate ovules in each chamber; style filiform, about as long as the stamens, stigma apical, shortly 3-lobed, papillate, exserted when stamens shrivel. Capsule broadly triangular, c. $18 \mathrm{~mm}$ long and broad, depressed in the centre, walls thin, greenish; seeds discoid, $7 \mathrm{~mm}$ in diam., black, shiny.

The perianth, with its recurved segments, resembles a Drimia flower but in all other respects it conforms to Ornithogalum. The segments, after anthesis, return to the bud position closing over the ovary. In the type-plant the recurving was very characteristic, as can be seen in the photographs, but in the other 

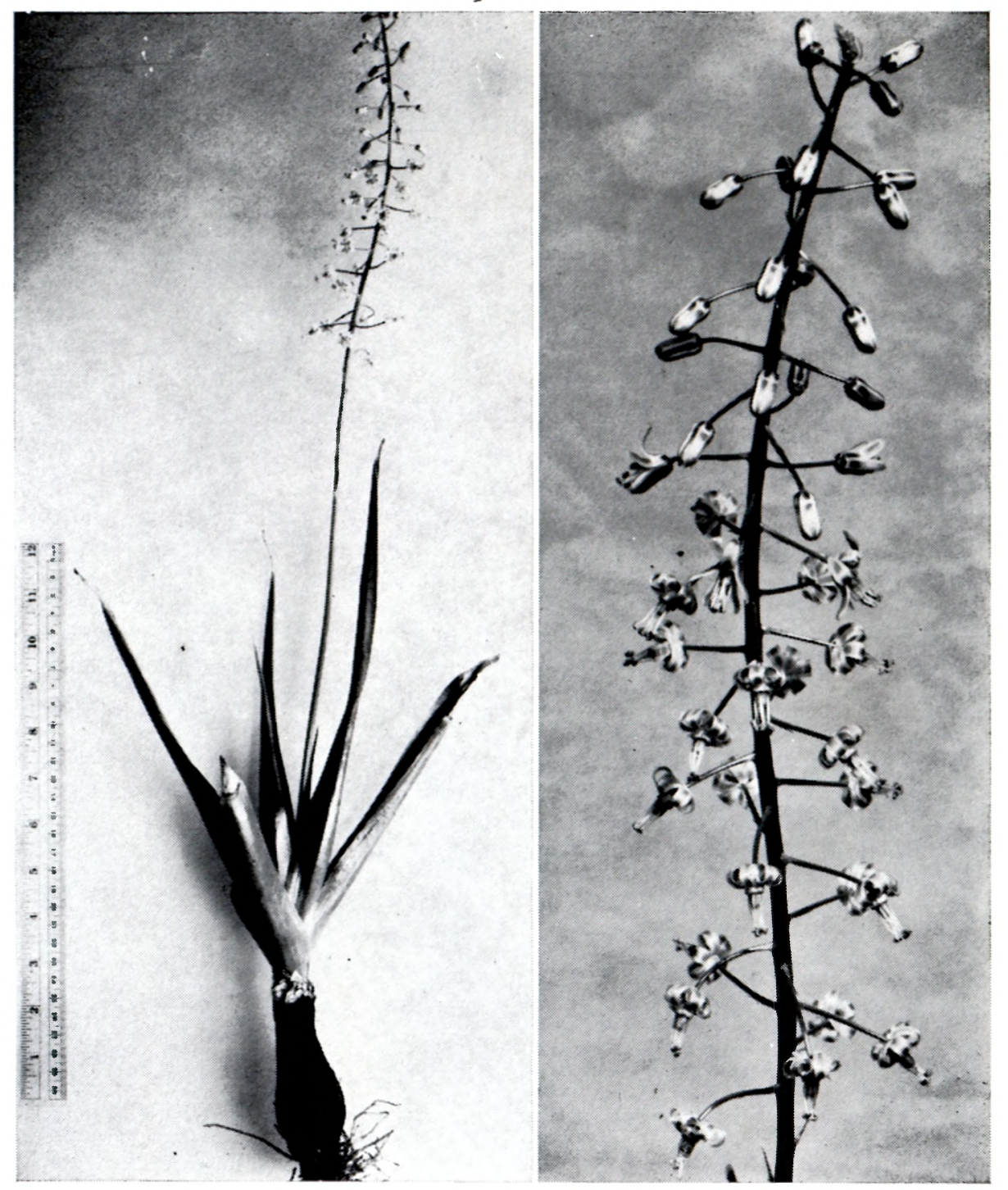

Plate 2. - Ornithogalum recurvum, Kaokoveld, South West Africa (Story 5848). (Whole plant at left, $\mathrm{x} \frac{1}{4}$; inflorescence at right, $\mathrm{x} 1$ ).

cited specimen, which was in the fruiting stage (De Winter \& Leistner 5732), this could not be observed as no flowers were present. A few staminal filaments, that had persisted below the capsule, showed the typical broadened bases and it matched the type in all other respects. The species is very near $O$. stapfii but the plant is larger, with the larger and broader leaves forming a distinct upright rosette, and the recurved perianth especially distinguishes it from that species. 